\title{
The Discount Rate, Interest Rates and Foreign Exchange Rates: An Analysis with Daily Data
}

\author{
Dallas S. Batten and Daniel L. Thornton
}

W

ITH the foreign exchange value of the U.S. dollax continuing to increase rapidly, the search goes on for explanations of this unprecedented rise. Explanations of exchange rate movements frequently focus on two factors: (1) changes in credit market conditions reflected by changes in interest rate differentials across countries and (2) changes in the monetary policy stances of central banks, especially those of the Federal Reserve.

In this article, the validity of these explanations is tested. Specifically, we investigate the impact of a change in U.S. short-term interest rates relative to those in Canada, France, Germany, Japan and the United Kingdom on the bilateral foreign exchange rates between the U.S. dollar and each country's currency.

Since there has been a particular focus recently on the impact of unexpected changes in monetary policy upon exchange rates, we investigate this also. Changes in the discount rate charged by the Federal Reserve on short-term loans to depository institutions are frequently considered to be an important indicator of the Fed's intentions. Moreover, discount fate changes have been shown to have a significant impact

Dallas $S$. Batten is a research officer and Daniel $L$. Thornton is a senior economist at the Federal Resenve Bank of St. Louis. Paul G. Christopher provided research assistance.

'See Cornell (1982, 1983), Engel and Frankel (1984) and Urich and Wachtel (1981). on the dollar's exchange value if these changes are unanticipated ${ }^{2}$ Consequently, these changes are in cluded to proxy changes in policy by the Federal Reserve. In addition, the analysis is conducted for both before and after October 1979 to investigate the effect of the Federal Reserve's decision to place more emphasis on the growth of reserves and less on the federal funds rate in the conduct of monetary policy.

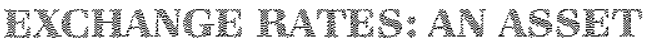 MAPERT}

The exchange rate is simply the price of one country's currency in tems of another's. It is determined in organized, efficient markets in the same manner as are the prices of other assets, such as stocks, bonds or real estate. Because these assets are durable, their current prices reflect people's perceptions of current events and expectations of future events as well. In other words, the current price of the asset reflects its expected future price. Consequently, any information that leads individuals to alter their expectations about the future price of an asset has an effect on the asset's current price.

'See Batten and Thornton (1984). The discount rate analysis here is an extension of the Batten-Thornton model. The distinction here is
that the use of bilateral exchange rates enables the inclusion of an extension of the Batten-Thornton model. The distinction here is interest rate differentials over the entire sample period. 
The assets involved in the determination of ex change rates are domestic money supplies. Thus, the fundamental determinants of exchange rate movements must include, among other things, the factors that affect the demand for and the supply of domestic monies. Obviously then, the monetary policy objectives of central banks, the market's perception of the future course of policy actions, and credit market conditions across countries play integral roles in determining exchange rates.

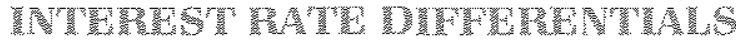

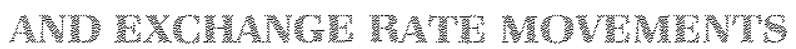

The relationship between nominal interest rate differentials and exchange rate movements is complex and ambiguous. The decision to reallocate portfolios and the associated capital flows does not depend simply on the nominal interest differential, but on this differential adjusted for the expected rate of appreciation or depreciation of the foreign exchange value of the dollar. ${ }^{3}$ In actuality, an incipient capital flow and the subsequent change in the exchange rate will occur only if the higher nominal interest rate in one country is not offset by an expectation of an equal-sized depreciation of that country's currency.

The expectation of future appreciation or depreciation of a currency is linked closely to the expectation of future inflation in one country vis-a-vis that in another. If the rate of inflation in the United States is expected to exceed that in Germany by 5 percent then, other things equal, the U.S. dollar would be expected to depreciate against the Deutsche mark (DM) by 5 percent. ${ }^{3}$ Since nominal interest rates contain both a real return and a premium for expected inflation, this expected inflation rate differential also would be reflected by nominal interest rates in the two countries. That is, if inflation is expected to be 5 percentage points higher in the United States than in Germany, U.S. nominal interest rates would be 5 percentage points higher than those in Germany, other things equal. Consequently, a nominal interest differw

${ }^{3}$ See Mudd (1979b), Batten (1981), Wiby (1981) and Bergstrand (1983).

In fact, if a rising (falling) interest differential is more than offset by increased expectations of exchange rate depreciation (appreciation), the spot exchange rate can actually depreciate (appreciate) even with a rising (falling) interest differential. See Mudd (1979b) and Batten (1981).

${ }^{5}$ For a discussion of this concept, called relative purchasing power parity, see Batten and Ott (1983). ential in favor of the United States would be associated with a depreciating dollar if this interest differential was caused by an expected higher rate of inflation in the United States relative to Germany.

In this regard, a changing nominal interest differential can reflect a change in either the real interest differential or the inflation differential. If it reflects a change in the inflation differential, the nominal differential and the exchange rate will move in opposite directions as above. If it reflects a change in the real differential, just the opposite occurs. In particular, when certain events (such as changes in tax laws, asset preferences or the relative price of energyl have different impacts on nominal interest rates and inflation rates - both actual and expected - the real interest differential will change as well, and the exchange rate will change in the same direction.

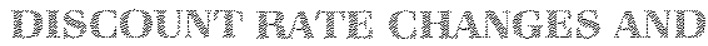

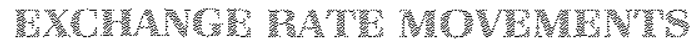

If a change in the discount rate, when announced, is to have a perceptible effect on the current exchange rate, it must (1) transmit (or be believed to transmit) some information about the policy intentions of the Federal Reserve and (2) be unanticipated. ${ }^{6}$ If the market expects a discount rate change, this expectation will be reflected by the exchange rate immediately. If the discount rate change represents an unexpected change in current or future monetary policy, it will be assinilated by the foreign exchange rate concomitant with the announcement of the discount rate change.

An unanticipated discount rate change may lead individuals to alter their expectations of the future course of monetary policy; however, there are several theories about the impact of such changes on the exchange rate. The nature of the effect depends criti-

\footnotetext{
"This discussion ignores the possibility of an indirect "liquidity effect," whereby an increase on the discount rate increases domestic interest rates and, hence, a decline in the foreign exchange value of the doflar. This is a possibility since Thornton (1982) has shown a temporary effect of discount rate changes on domestic interest rates.

'The incorporation of discount rate changes into the analysis in this manner creates an identification problem. It is impossible to determine whether it is the actual discount rate change or the announcement of new information that affects the foreign exchange value of the dollar.

These have been offered as possible explanations of the potential impact of unanticipated money supply announcement on the exchange rate. See Cornell (1983).
} 
cally on how the announcement reshapes expectations. For example, an unexpected increase in the discount rate may be interpreted as a tightening of current monetary policy and, consequently, may generate expectations that the Fed will counteract this move with a relatively looser policy in the future. In this case, the market would bid down current real interest rates, expecting them to be realized subsequently. Consequently, the foreign exchange value of the dollar would depreciate as nominal interest rates fall in the short run, reflecting the lower ex ante real rates.

On the other hand, this same increase may simply motivate widespread anticipation of continued monetary tightening. In this instance, individuals might expect a lower rate of U.S. inflation relative to that in the rest of the world. This will generate expectations of future appreciation of the U.S. dollar, which will be discounted into an appreciation of the current exchange rate, accompanied by lower nominal interest rates as inflation expectations fall.

This inflationary expectations effect may not be distinguishable from an initial liquidity effect. In other words, the rise in the discount rate may cause an initial rise in U.S. real interest rates and, hence, an initial widening of the interest rate differential. Consequently, an increase in the discount rate may cause the foreign exchange value of the dollar to rise through either liquidity or inflationary-expectations effects.

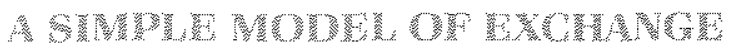

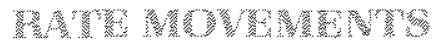

To examine the possible announcement effect of a discount rate change and the possible impact of changes in the nominal interest differential, we specify a simple model of daily exchange rate movements. In addition to these variables, the model should include numerous variables that are commonly considm ered to influence the dollar price of foreign currencies, such as U.S. and foreign money stocks, real incomes, expected long-term inflation rates and current account balances." Unfortunately, observations on these variables are not available on a daily basis. As an alternative, we simply employ a distributed lag of past exchange rate changes.

\footnotetext{
9This so-called "policy anticipation effect" is attributed to Urich and Wachtel (1981).

SSee, for example, Meese and Fogoff (1983).
}

Furthermore, only unanticipated discount rate changes should be important in an empirical model. Since the usual procedure for estimating these unexpected changes / through modeling expected discount rate changes) is inappropriate because of the discrete nature of these changes, actual discount rate changes are employed here. We do, however, attempt to lessen the potential bias associated with using the actual discount rate changes by (1) introducing a distributed lag of the change in the difference between the federal funds rate and the discount rate as a proxy measure of the market's anticipation of future discount rate changes and (2) employing the reasons for the change given by the Fed when the change is announced to partition the set of discount rate changes.

There is an intuitive rationale for using the distributed lag of changes in the federal funds rate/discount rate spread to measure anticipated changes in the discount rate. During approximately half of the period that we analyzed, the Fed attempted to maintain a relatively narrow spread between these rates. Thus, an atypical and prolonged widening or narrowing of this spread could have signaled that a discount rate change was imminent. Given the asset approach to exchange rate determination, such anticipated discount rate changes would then be reflected by a change in the exchange rate prior to the actual announcement of the change in the discount rate. Including a distributed lag of the federal funds rate discount rate spread should help account for such effects.

Furthemore, when the Fed announces a discount rate change, it states the reason for the change. Consequently, discount rate changes can be partitioned into two groups according to the reason accompanying them: technical or policy-related.

Discount rate changes made solely to bring the discount rate into closer alignment with short-term market rates are merely technical adjustments and do not reflect changes in monetary policy. Using this information to partition the actual discount rate changes should lessen the potential downward bias for two reasons: First, discount rate changes made purely for technical reasons are less likely to be interpreted as indicating a change in Federal Reserve policy. Hence, it is less likely that there is an announcement effect associated with them. Second, they are more likely to be anticipated, so that any policy-related information they might contain is likely to be incorporated into the current exchange rate before the change in the discount rate. Finally, during the period analyzed, the policy-related reasons included both domestic and 
international objectives. Consequently, the policy-motivated discount rate changes were partitioned accordingly.

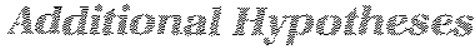

Besides the hypotheses already presented, several others of interest can be tested within this framework. First, Mudd (1979a) has proposed that the November 1, 1978 discount rate change should have had a substantially larger impact on the foreign exchange value of the dollar than others did (even those made for policy reasons) because it was accompanied by several other Fed actions that were intended to strengthen the dollar. ${ }^{33}$ The most important of these was the stated intent of the Fed and Treasury to intervene more actively in foreign exchange markets, which was accompanied by an arrangement through which the United States floated foreign-currency-denominated debt to obtain funds to finance this intervention. To investigate this proposition, we partitioned the data by separating the discount rate change on November 1, 1978, from the others made for international reasons.

Furthermore, we investigate the possible impact of U.S. intervention in foreign exchange markets by separating discount rate changes made for international reasons during periods when the United States actively intervened from those made during the rest of the sample period. The United States has typically intervened infrequently in foreign exchange markets, leaving that activity primarily to foreign monetary authorities. With strong downward pressure on the dollar during 1978, however, the Fed and the U.S. Treasury adopted a more activist intervention policy: from November 1978 to March 1981, they intervened frequently and in large amounts. This dramatic change in policy might have altered the impact of unanticipated discount rate changes on the foreign exchange value of the dollar.

Finally, we partitioned the discount rate changes made for domestic reasons at October 6,1979 , the date the Fed changed its operating procedure for implementing domestic monetary policy. On that date, the Fed announced that it was placing greater emphasis on bank reserves and less emphasis on the federal funds rate in conducting day-to-day open market operations. ${ }^{12}$ After this change, the spread between the federal funds and the discount rates became larger and more variable than it was before. Consequently, all

\footnotetext{
"See Mudd (1979a) for details

₹25ee Lang (1980).
}

discount rate changes, including those made for policy reasons, may be less predictable (and, hence, more likely to have an impact on the exchange rate) under the reserves targeting procedure than they were under the federal funds rate targeting procedure.

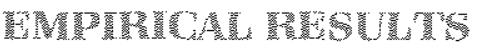

To test the hypotheses outlined above, variants of the following equation were estimated using daily data for the period January 2, 1975, to October 31, 1984:

$$
\text { (1) } \begin{aligned}
\Delta \ln \mathrm{S}_{\mathrm{s}}=\alpha & +\sum_{\mathrm{i}=1}^{7} \beta_{\mathrm{i}} \Delta \ln \mathrm{S}_{\mathrm{s}-\mathrm{i}}+\sum_{\mathrm{i}=1}^{7} \gamma_{\mathrm{i}} \Delta\left(\text { FFR-DR }_{\mathrm{t}-\mathrm{i}}\right. \\
& +\phi \Delta \mathrm{DR}_{\mathrm{t}}+\eta \Delta \operatorname{RDIFF}_{\mathrm{t}}+\varepsilon_{\mathrm{t}}
\end{aligned}
$$

where

$S=$ the U.S. dollar price of a unit of foreign currency on day $\mathrm{t}$.

FFR = the U.S. federal funds rate,

DR = the U.S. discount rate, and

RDIFF $=$ the difference between the U.S. 90-day CD rate and a comparable foreign short-term interest rate.

The currencies included are those of Canada, France, Germany, Japan and the United Kingdom. ${ }^{14}$ There were 37 changes in the discount rate during this period. Of these, 16 were made solely for technical reasons, 14 included domestic (but not international) monetary policy considerations and seven included international policy considerations."

The results are reported in tables 1-5. Because the estimated coefficients of $\triangle D R$ (and its partitions) and $\triangle \mathrm{RDIFF}$ are the focus of this analysis, only these estimates are presented. Of particular interest are the relatively low adjusted $R^{2} s$ across the estimation for all countries. These support the basic conclusion of the asset market approach to exchange rate determination, that is, that most of the variance of exchange rate movements is attributable to unexpected events. Nonetheless, as the F-statistics demonstrate, all of the estimations are statistically significant at the 5 percent level.

\footnotetext{
13The lag length chosen for each distributed lag was the longest period possible without overlapping discount rate changes. Also, a distributed lag of $\triangle R D$ RIFF was included initially, but did not add to the explanatory power of the estimated equation for any currency.

${ }^{14}$ These countries make up the over 68 percent of the trade-weighted exchange rate,

${ }^{5}$ See Batten and Thornton for a more detailed discussion, a presentation of discount fate changes during this period and the reasons given for these changes.
} 


\section{Table 1}

\section{Estimation of Equation 1}

\begin{tabular}{|c|c|c|c|c|}
\hline \multirow[b]{2}{*}{ country } & \multicolumn{4}{|c|}{ Estimated Paraneters } \\
\hline & $\triangle \mathrm{DP}$ & ARDIF & $\overline{\mathrm{A}} \mathrm{SE}$ & $F$ \\
\hline Cenada & (1.002) & $0.00081 ?$ & $\begin{array}{l}0.0146 \\
0.0023\end{array}$ & 3.37 \\
\hline France & $(4.65)^{0.00648^{\circ}}$ & 0.00561 & $\begin{array}{l}0.0687 \\
0.0057\end{array}$ & 12.83 \\
\hline Gernany & $\begin{array}{c}0,00730 \\
(5,43)\end{array}$ & 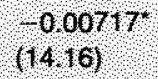 & $\begin{array}{l}0.0975 \\
0.0055\end{array}$ & 18.32 \\
\hline Japan & $\begin{array}{l}0.00100 \\
(0.72)\end{array}$ & $\begin{array}{l}0.00614 \\
(10.92)\end{array}$ & $\begin{array}{l}0.0518 \\
0.0057\end{array}$ & 9.75 \\
\hline $\begin{array}{l}\text { United } \\
\text { Kingdont }\end{array}$ & $\left(0.00363^{\prime}\right.$ & $\frac{\left(0,0027^{9}\right.}{(6.96)^{\prime}}$ & $\begin{array}{l}0.0265 \\
0.0055\end{array}$ & 5.36 \\
\hline
\end{tabular}

Absolute values of t statistics in parentheses. Statistically significant at the 5 percent level

For each of the currencies except that of Japan, there is a statistically significant lat the 6 perent level for Canada) announcement effect associated with discount rate changes (table 1). Furthermore, when the U.S. discount rate is increased (decreased), the U.S. dollar appreciates (depreciates) against each of these currencies, a result that tends to support the inflationary expectations hypothesis. ${ }^{26}$ A 1 percentagepoint change in the discount rate (for whatever reason) motivates an exchange rate change that ranges from a low of 0.11 percentage points in Canada to a high of 0.73 percentage points in Germany, all other things constant. This result is economically, as well as statistically, significant as the average absolute daily exchange rate change during this period ranged from 0.16 percent in Canada to 0.40 percent in Germany.

Changes in the interest differential exhibited a statistically significant impact on daily exchange rate movements for every country in the sample. Moreover, in each case, an increase (decrease) in the interest differential generated an appreciation (depreciation) of the dollar exchange rate.

The magnitude of the impact, however, differed substantially across countries. For example, the U.S.

\footnotetext{
"Since $S$ is the U.S. dollar price of a unit of foreign currency, a negative sign for an estimated parameter in equation 1 indicates that an increase in that right-hand-side variable causes $S$ to decline, or, alternatively, the foreign currency price of a U.S. dollar (1/S) to rise. So, e.g., the negative coefficient on $\triangle \mathrm{DR}$ indicates that an increase (decrease) in the U.S. discount rate causes the foreign exchange value of the dollar to appreciate (depreciate).
}

dollar/Deutsche mark exchange rate was the most af fected, changing by roughly 0.72 percent for each per centage-point change in the interest differential. Al ternatively, the U.S. dollar/ Canadian dollar exchangf rate moved only 0.08 percent for each percentage point change in the interest differential.

When the discount rate changes are partitioned ac cording to the reason given for the change (table 2), the results differ across countries. One common point however, is that discount rate changes made for technical reasons never have an announcement effect for any currency. This is to be expected because these changes do not represent changes in Fed policy. Discount rate changes made for domestic reasons are statistically significant in three of the five cases: Can. ada, France and Gemany. Changes made for international reasons are significant for each country excep 1 Canada and have an impact four to 10 times large than those of changes made for domestic reasons. In the case of Japan, however, the effect is due solely tc the discount rate change on November 1, 1978, as noted below.

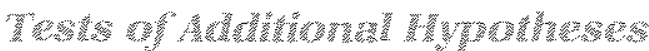

The separation of the discount rate change made on November 1, 1978, from the others made for intemational reasons (table 3 ) reveals that this was indeed an important discount rate change. Its impact was significant for every country except Canada and four to six times larger than the impact of other changes for international reasons. Moreover, the November 1. 
Table 2

\section{Estimation of Equation 1 with Discount Rate Changes Partitioned by Reason}

\begin{tabular}{|c|c|c|c|c|c|c|}
\hline \multirow[b]{2}{*}{ Country } & \multicolumn{6}{|c|}{ Estimated Parameters } \\
\hline & SDRDOM & $\triangle O D A N T$ & ADHTECH & ARDiFF & n'se & $F$ \\
\hline Canada & $\left(2,0077^{\circ}\right.$ & $(1,77)$ & $(000000$ & $(4.35)^{0}$ & 0.0147 & 3.12 \\
\hline France & $(2,00504$ & $(7.63)$ & $\begin{array}{l}0.00064 \\
(0.28)\end{array}$ & $(11.37)^{0}$ & $\begin{array}{l}0.0832 \\
0.0057\end{array}$ & 1302 \\
\hline Germany & $(300394$ & $\left(0.02585^{\circ}\right.$ & (0,00001 & $\left.(14.06)^{0}\right)^{\circ}$ & 0,1130 & 19.15 \\
\hline sapan & $(0.00175$ & $(461469)$ & $(0,00296$ & $\left.(10.00)^{0}\right)^{\circ}$ & $\begin{array}{l}0.0592 \\
0.0056\end{array}$ & 996 \\
\hline $\begin{array}{l}\text { United } \\
\text { Kngdon }\end{array}$ & $\begin{array}{l}0.00182 \\
(0.92)\end{array}$ & $\begin{array}{l}0.01642^{\prime} \\
(5,17)^{2}\end{array}$ & $\begin{array}{l}0.00033 \\
(0.15)^{\prime}\end{array}$ & $\begin{array}{l}0.00275^{\circ} \\
(6,86)\end{array}$ & $\begin{array}{l}0.0334 \\
0.0055\end{array}$ & 5.92 \\
\hline
\end{tabular}

Absollte value of $t$ statistic in parentheses. Statisticaly significant at the 5 percent level.

ADRDOM discount rate changes for domestic reasons ADRINT 4 discount ate changes for intemational reasons

$\triangle O R I E C H$ - discount rate changes for technical reasons

\section{Table 3}

\section{Estimation of Partitioned Equation 1 with Emphasis on November 1, 1978}

\begin{tabular}{|c|c|c|c|c|c|c|c|}
\hline \multirow[b]{2}{*}{ country } & \multicolumn{7}{|c|}{ Estimated Parameters } \\
\hline & ODRDOH & 40Fnovia & AproikT & SOPTESH & $\triangle A D P F$ & Fise & f \\
\hline Canada & $(2009)^{\circ}$ & 0.00095 & 40.00270 & $(0,000)$ & $(4,390)$ & $\begin{array}{l}00150 \\
0,0020\end{array}$ & 3.05 \\
\hline France & $\frac{(2.49)^{\circ}}{\left(400506^{\circ}\right.}$ & $\begin{array}{c}0.05035^{\prime} \\
(8.88)^{\prime}\end{array}$ & $\begin{array}{l}001249^{\circ} \\
(3,7)^{\circ}\end{array}$ & $\begin{array}{l}0.00065 \\
(0.29)\end{array}$ & $(0,00554$ & 0.0935 & 14.92 \\
\hline Germany & $\begin{array}{l}0.00602 \\
(3,10)\end{array}$ & $\begin{array}{c}0,05658 \\
10,37)^{\circ}\end{array}$ & $\left(201095^{\circ}\right.$ & $\begin{array}{l}0.00004 \\
(0.02)\end{array}$ & $\left(\begin{array}{l}0,00708 \\
(1423)\end{array}\right.$ & 01288 & 20.94 \\
\hline Japan & 0.00112 & $\frac{-0,03361 \%}{(5.95)^{\circ}}$ & -0.00552 & 0.00303 & $\left.(1090)^{\prime}\right)^{\circ}$ & 0.0649 & 10.37 \\
\hline United, & $(0.9018)$ & $(0.0314)^{\circ}$ & $\begin{array}{l}0.00915 \\
(2.37)\end{array}$ & $(0,00037$ & $(6009)$ & 00375 & $6.20 \%$ \\
\hline
\end{tabular}

Absolute value of 1 statistics in parentheses. Statisticaly signiticant at the 5 percent level:

$\triangle D R D O M$ - discount rate changes for comestic reasons

$\triangle D O R N O V 78$ - discount rate change on November 1,1978

$\triangle D R O N T$ - discount rate changes for international reasons other than on November 1,1978

$\triangle D R T E C H$ - discount rate changes for technical reasons

1978 change was the only discount rate change during the period to have any impact on the dollaryen exchange rate. This impact was extremely large, with a 1 percentage-point change in the discount rate leading to a 3.36 percent change in the dollar/yen rate, all other things constant, compared with the average absolute change in the dollar/yen rate during this period of only 0.38 percent. Finally, for the three currencies for which international changes other than that on November 1, 1978, had a statistically significant effect (those of France, Germany and the United Kingdom), this impact was significant only during the period in which the Fed was actively intervening in foreign exchange markets (table 4). 


\section{Table 4}

\section{Estimation of Partitioned Equation 1 with Emphasis on Intervention}

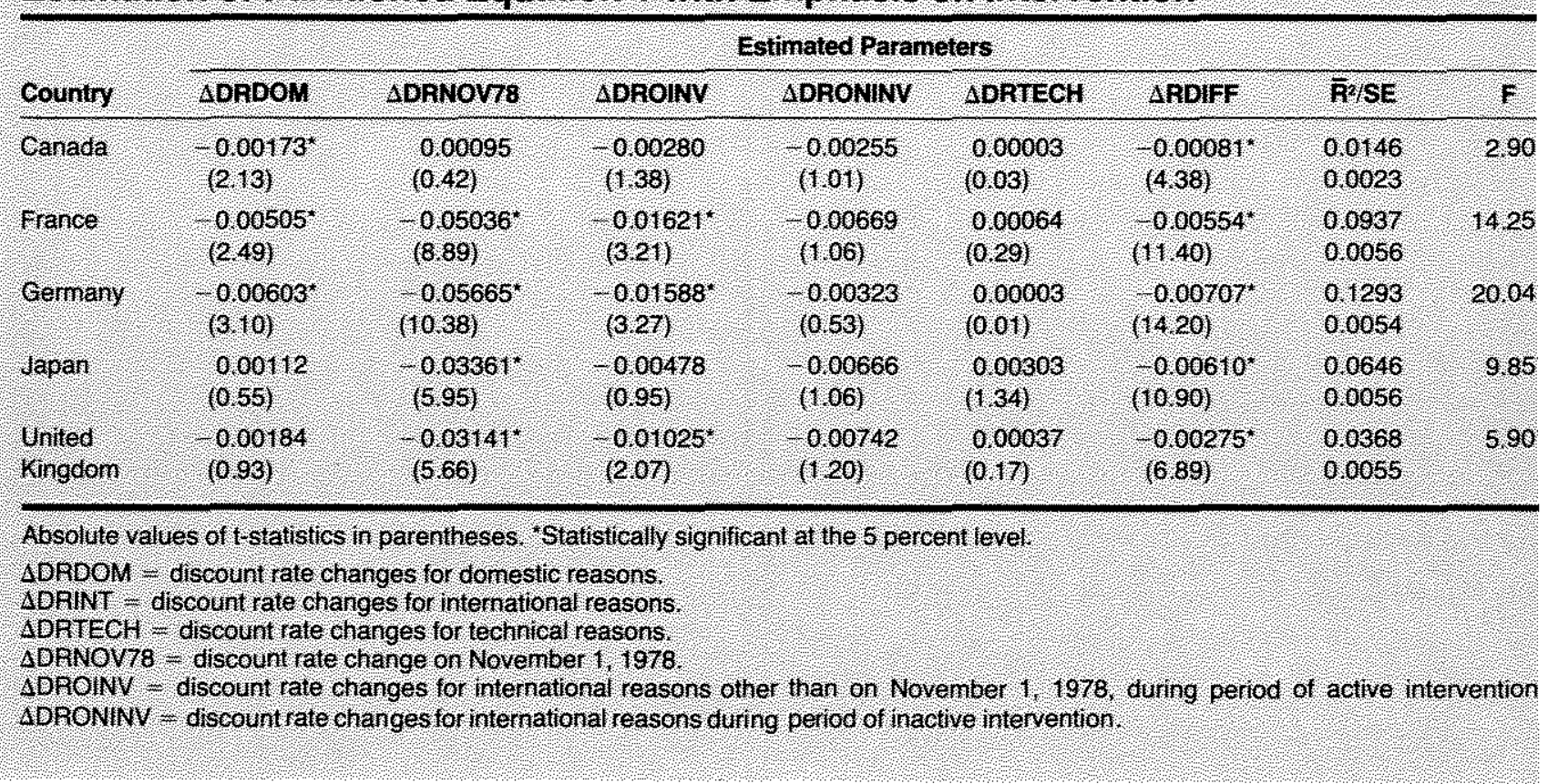

\section{The Mcholy

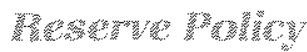

The possible impact of the change in Federal Reserve policy procedure in October 1979 is examined in table 5 . This examination was implemented by partitioning $\triangle D R D O M$ and $\triangle R D I F F$ at October 6,1979 , in the variant of equation 1 where discount rate changes are partitioned by reason. ${ }^{17}$ The results for $\triangle D R T E C H$ and $\triangle D R I N T$ are consistent with those in table 2. Specifically discount rate changes made for technical reasons had no significant announcement effect, while those made for international reasons did for all currencies except the Canadian dollar. Furthermore, for the currencies for which discount rate changes made for domestic reasons have significant announcement effects over the entire period (Canadian dollar, French franc and Deutsche mark), these effects were significant only after October 1979.

Only three of the 14 changes on the discount rate for domestic policy reasons occurred during the pre-

\footnotetext{
"Since only the discount rate and interest rate differential variables are of interest, the parameters in the other variables were assumed to be the same over both periods.
}

October 1979 period. Nonetheless, these pre-Octob 1979 changes did not have a significant effect on t] foreign exchange value of the dollar for any countr. While this result is based on relatively few discou rate changes, it does suggest either that discount ra changes were more readily anticipated or that evi unanticipated changes contained little useful infc mation when the Federal Reserve's primary policy o jective was to smooth or stabilize short-term intere rates.

An interesting result emerging from this partitio ing is that changes in the interest differential were $n$ statistically significant before October 6 , but we highly significant afterward. (This effect, however, $w$ significant at the 10 percent level in the earlier peric for the dollar/DM rate. But even in this case, the ir pact is four times larger after October 6, 1979, than was before. A possible explanation for this is that $t$ period between January 1, 1975, and October 6, 197 was one in which both the rate of U.S. money grow and the rate of U.S. inflation accelerated dramatical relative to those in the rest of the world. Consequent] changes in the U.S. nominal interest differential pi marily may have been reflecting changing inflationa expectations; thus, these changes had no statistical significant impact on the foreign exchange value of $t$ dollar. 
Table 5

Estimation of Partitioned Equation 1 with $\triangle D R D O M$ and $\triangle R D I F F$ Partitioned at October 6,1979

\begin{tabular}{|c|c|c|c|c|c|}
\hline \multirow[b]{2}{*}{ Variable } & \multicolumn{5}{|c|}{ Estimated parameters tor } \\
\hline & Canada & France & Germany & Japan & UK. \\
\hline$\triangle D F O O M$ & $(0,000)$ & $(0,000)$ & $(0,30)$ & $(0,00168$ & $(0.54)^{0}$ \\
\hline$\triangle 0 R D O M 2$ & $\begin{array}{l}0.00189^{\circ} \\
(2.22)\end{array}$ & $=0,0044^{\circ}$ & $\frac{0.00535^{\circ}}{(2.60)}$ & $\begin{array}{l}0.00149 \\
(0.69)^{\circ}\end{array}$ & $(0.00080$ \\
\hline SBRINT & $(0,22)$ & $(0,0264)^{\circ}$ & $\begin{array}{l}0.02690^{\circ} \\
(856)^{\circ}\end{array}$ & $(4.97)^{-01620}$ & $(5,30)$ \\
\hline$\triangle D P T E C H$ & $(0.01)$ & $(0.00089$ & $\begin{array}{l}0,0000 \\
(0,01)\end{array}$ & $(1,35)^{0}$ & $(0,000)^{\circ}$ \\
\hline AROIFI & 0,00019 & 0,00098 & $\frac{0.00219}{9.71}$ & $(0.809)^{22}$ & $\begin{array}{l}0.00050 \\
(0.73)\end{array}$ \\
\hline$\triangle$ SOFF? & $(4,72)$ & $(13.29)$ & $(1460)^{9}$ & $(11,47)^{\circ}$ & $(900)$ \\
\hline$n$ & @ 00155 & 0,0989 & 01183 & 00639 & 0.0453 \\
\hline SE & \& 0,0023 & 00056 & 0,0054 & 0,0056 & 0.0055 \\
\hline 5 & $3.02 \%$ & $15.08^{\circ}$ & 18.20 & 975 & 709 \\
\hline
\end{tabular}

Absolute values of t statistics in parentheses, Statistically significant at the 5 percent level.

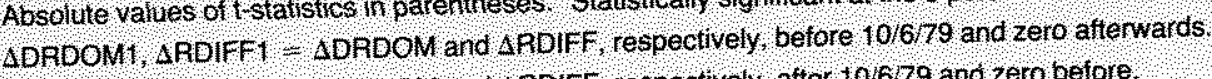

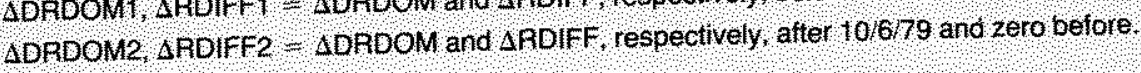

On October 6,1979 , the Fed announced that it was placing increased emphasis on reserve aggregate control. Since that time the inflation rate has declined dramatically. Within this environment, changes in the nominal interest differential, in the short run, have meant concomitant changes in the real interest differential and, hence, these changes had a positive impact on the foreign exchange value of the dollar. ${ }^{18}$

\footnotetext{
8this conjecture is corroborated by chari 3 in Batten and Ott. In particular, using observed inflation rates to calculate real interest rates, real interest differentials and nominal interest oufferentials actually moved in opposite directions during most of the earlier period, but moved together during the later period. Furthemore, it does not appear that this result is due to just a procedural change. does the fargeting. In October 1982, the Fed dropped $\mathrm{M} 1$ as an explicit intermediate target and adopted a very different operating procedure which is similar to targeting on the federal funds rate over short periods of time (see Gilbert (1985) for detais). When the data are partitioned to reflect this change, the coefficients of $\triangle$ RDIFF remain negative and statistically significant in the post-Octaber 1982 period.
}

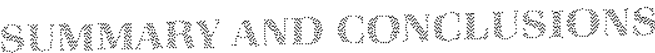

The purpose of this article has been to test for the effects of changes in short-term interest differentials and unanticipated changes in U.S. monetary policy on the foreign exchange value of the dollar. Using changes in the discount rate as a proxy for unanticipated changes in U.S. monetary policy, we find that, in general, both of these factors have a significant impact on daily movements of the bilateral exchange rate between the U.S. dollar and the Canadian dollar, French franc, Deutsche mark, Japanese yen and British pound

The evidence suggests that discount rate changes made for other than technical reasons have not been fully anticipated and, consequently, have had both a statistically and an economically significant impact on the U.S. dollar exchange rate with the five currencies examined. Furthermore, changes in interest rate differentials motivate exchange rate movements only if 
they are not neutralized by offsetting changes in expected exchange rate movements. It appears that this was the case only during the period when the Federal Reserve followed a decidedly disinflationary policy.

The reader is cautioned, however, that the majority of daily exchange rate movements are explained by events other than previous exchange rate movements, discount rate changes and interest differential changes. The simple model estimated here never explained more than 15 percent of the variance of daily changes in these five exchange rates.

\section{W1}

Batten, Dallas S. "Foreign Exchange Markets: The Dollar in 1980," this Review (April 1981), pp. 22-30.

Batten, Dallas S. and Mack Ott. "Five Common Myths About Floating Exchange Rates," this Review (November 1983), pp. 5-15.

Batten, Dallas S., and Daniel L. Thomton. "Discount Rate Changes and the Foreign Exchange Market, "Journal of International Money and Finance (December 1984), pp. 279-92.

Bergstrand, Jeffrey $\mathrm{H}$. "Selected Views of Exchange Rate Determination after a Decade of 'Floating'," New England Economic Review (May/June 1983), pp. 14-29.
Cornell, Bradford. "Money Supply Announcements, Interest Rat and Foreign Exchange," wournal of International Money and nance (August 1982), pp. 201-08.

. "The Money Supply Announcements Puzzle: Revi and interpretation," The American Economic Review (Septeml 1983), pp. 644-57.

Engel, Charles, and Jeffrey Frankel. "Why Interest Rates Reacl Money Announcements," Journal of Monetary Economics (Janu; 1984), pp. 31-39.

Gilbert, R. Alton. "Operating Procedures for Conducting Monet: Policy," this Review (February 1985), pp. 13-21.

Lang, Richard W. "The FOMC in Y979: Introducing Reserve Targ ing," this Review (March 1980), pp. 2-25.

Meese, Richard A., and Kenneth Rogofi. "Empirical Exchange R; Models of the Seventies: Do They Fit Out of Sample?" Joumai International Economics (February 1983), pp. 3-24.

Mudd, Douglas R. "Did Discount Rate Changes Affect the Forei Exchange Value of the Dollar During 1978?" this Review (A) 1979a), pp. 20-26.

"Do Rising U.S. Interest Rates Imply a Stronger D lar?" this Review (June 1979b), pp. 9-13.

Thornton, Daniel L. "The Discount Rate and Market Interest Ratt What's the Connection?" this Review (June/July 1982), pp. 3-1

Urich, Thomas, and Paul Wachtel. "Market Response to Weekly Money Supply Announcements in the 1970s," Joumal Finance (December 1981), pp. 1063-72.

Wilby, William L. "interest Rates and Exchange Rates Under $t$ Fed's New Operating Procedure: The Uneasy Marriage," Ec nomic Perspectives (September/October 1981), pp. 3-13. 